\title{
Contribution to the study habits learning outcomes in senior high school
}

\author{
Debi Agustin ${ }^{1}$, A. Muri Yusuf ${ }^{2}$, Sufyarma $^{3}$ \\ ${ }^{123}$ Universitas Negeri Padang, Padang - Indonesia
}

\begin{abstract}
Results of study is a benchmark in view the success of student learning. The level of achievement of learning outcomes allegedly influenced by many factors. Study habits and is one of the factors suspected to affect learning outcomes. This study aimed to describe the contribution of the habit of learning on student learning outcomes. This study uses a quantitative approach a descriptive correlational. The study population 212, and a sample of 139 students obtained via technique. Proportional Random Sampling instruments used are instruments of learning habits, while the study results obtained from the value of student learning outcomes. Analysis of data using simple regression techniques. The research result shows that the habit of learning and learning outcomes at the high category. Contributions habit of learning to the learning outcomes $32.9 \%$.
\end{abstract}

Keywords: habits of learning, learning outcomes.

\section{Introduction}

Education is an organization in gaining knowledge, and place in order to optimize our potential. Humans can be said to be educated if it can be put, and to optimize the cognitive, affective, and psychomotor owned by him. Such education can be achieved through a school or similar institution that is seen by the public community. states that education is a conscious effort, planned and intended to enable students to actively develop their potential, both physical and non-physical, which was to develop the potential of thought (mental-intellectual), social, emotional, moral, spiritual, by economists (life skills), physically, and culturally, so that she can run her life and living in accordance with the expectations of herself, her family, community, nation and state.

Containers in gaining formal education is education that school, so the school should be able to create a quality generation of cognitive, affective, and psychomotor through the learning process. Similarly, Slameto (2010) describes learning is a process attempts person to obtain a new behavior change overall, as a result of his own experience in interaction with the environment.

Achievement of learning objectives of the students is measured from the study, one of the main affecting learning achievement depends on factors of learning itself. Broadly speaking, the factors that affect student learning outcomes divided into two external factors and internal factors. Syah (2011) defines the factors affecting learning outcomes there are three, namely internal factors, external and learning approaches. Internal factors include the physiological and psychological aspects of the level 
of intelligence, attitude, aptitude, interest and motivation. External factors such as social environment such as teachers, educators, friends, whereas the environmental non-social, including the school building and its location, the house student residence and the location, learning tools, learning habits of students, the weather and the time of learning used students, while learning approach is the kind of effort students include the methods used to conduct study student learning materials.

One of the factors that influence student learning outcomes is the study habits of students. Thorndike (Alizamar, 2016) explains that the essence of learning is the process of establishment of relations between stimulus and response by following the laws, which one among these laws is the law of exercises that can be interpreted more often a knowledge that has been formed by the association between stimulus and trained response, then the bond will be stronger. Djaali (2014) also revealed a habit of learning is a way or technique that settled on students at a time to accept the lesson, read a book, tasks, and the timing to complete the activities. Habit learning is a way or method performed by a person repeatedly, and eventually became a precision and automatic. Effective habits required by each individual in learning activities, because it influences the understanding and learning outcomes that will be achieved. Habit learning is associated with learning the skills of a person. Learn skills in a way that is used to gain knowledge or how to resolve the problem. In this case, the student's skills in question, namely how to learn, how to learn, how to read and how to make summary.

How do different students, which means that skills in learning undertaken by students is also different. Students will realize how good learning, so that students will become more accountable learning activities. Good study skills will form good study habits as well. Therefore, the formation of habits of learning need to be developed. Student study habits are formed at school and at home, student learning activities carried out repeatedly during the learning process at school and learning activities conducted in the house. Good study habits would be a way rub off on students, so that students will do it with pleasure and no coercion. Based on the articles cited in DetikNews (2016) stated UN High School in 2016. The result is the average value of the UN High School decreased by 3 points from last year. Education Minister explain this decline due to increased UN Integrity Index.

The phenomenon that researchers have encountered in the field through interviews with school counselor and observations from Senior high school, began on January 10, 2017 until January 14, 2017 found: learning outcomes grade students who appear to be low through test results XI due to not learn and often played with their peers, many students of class XI chores at school to follow their peers, a lot of class XI students who often pull the follow peers that affect learning outcomes. Based on the above problems, the authors are interested in conducting research in Senior high school on "Contribution to the Study Habits Learning Outcomes in Senior High School". The purpose of this study are: (1) describe the learning outcomes of study habits in high school, (2) contribution to the learning outcomes study habits in high school.

\section{Method}

This study uses a quantitative approach with descriptive correlational. The population is all class XI Senior high school, amounting to 212 students. Sampling with technique proportional random sampling samples obtained 139 students. The instrument used was an instrument study habits, while the study results derived from the value of student learning outcomes. To determine the contribution of independent variables on the dependent variable, then the data were analyzed with simple regression. Assisted data analysis using SPSS version 20.00.

\section{Results and Discussion}

The data of this study consists of study habits variable $(X)$ and learning outcomes $(Y)$. The following description of the research data. 
1. Study Habits

Table 1. Frequency and Percentage Distribution Study Habits (X1)

\begin{tabular}{clcc}
\hline Interval Score & \multicolumn{1}{c}{ Category } & F & \% \\
\hline $\mathbf{1 4 0 - 1 6 5}$ & Very High (ST) & 41 & 29.50 \\
$\mathbf{1 1 4 - 1 3 9}$ & Height (T) & 53 & 38.13 \\
$\mathbf{8 8 - 1 1 3}$ & Medium (S) & 25 & 17.99 \\
$\mathbf{6 2 - 8 7}$ & Low (R) & 20 & 14.39 \\
$\mathbf{5 6 1}$ & Very Low (SR) & 0 & 0.00 \\
& Total & 139 & 100 \\
\hline
\end{tabular}

Table 1 shows the results of that study habits N 1 Two high school students Koto are in category (T) that is equal to $38.13 \%$, most of the other students in the category (s) that is equal to $17.99 \%$, then the category (ST) that is equal to $29.50 \%$, and the category (R) that is equal to $14.39 \%$. From the results of the general study habits high school students at the high category.

2. Study Results

Table 2. Frequency and Percentage Distribution of Learning Outcomes (Y)

\begin{tabular}{lllll}
\hline \multicolumn{1}{c}{ Categories } & \multicolumn{1}{c}{ Interval Score } & F & \% \\
\hline Very Good & $>89$ & 8 & 5.75 \\
Good & $80-89$ & 46 & 33.09 \\
Medium & $70-79$ & 40 & 28.78 \\
Low & $60-69$ & 39 & 2806 \\
Very Low & $<59$ & 6 & 4.32 \\
Total & & 139 & 100 \\
\hline
\end{tabular}

Table 2 shows that of the total sample of 139 students, the majority of student learning outcomes that are in both categories with the percentage of $33.09 \%$, most of the other students in the category with a percentage 28.78 , lower category with a percentage of 28.06 , very good category with a percentage of 5.75 and very low category with a percentage of 4.32 .

\section{Testing Requirement Analysis Data}

Test requirements analysis undertaken in this study is a test for normality, linearity test, and a test multicollinearity.

1. Normality Test

Normality test using the Kolmogorov-Smirnov showed that research was normally distributed variable data, with the value Asymp. Sig. learn custom variable of 0.150

2. Test Linearity linearity test results indicate that the variable data study habits to learning outcomes is linear with the Sig.0.000 $\leq$ 0:05.

3. Test Multicolinearity

Multicolinearity test results showed that there were multicollinearity between the variables of study habits and learning outcomes by VIF study habits of $1,040<10$.

\section{Hyphothesis Testing Research}

Contributions Habits Learning at Learning Outcomes.

The results of the analysis study habits contribute to learning outcomes can be seen in Table 3. 
Table 3. Regression Analysis Simple and Significance $\mathrm{X}_{1}$ to $\mathrm{Y}$

$\begin{array}{ccc}\text { Variable } & \mathrm{r} & \mathrm{R} \text { Square } \\ \mathbf{X}_{1}-\mathbf{Y} & 0.574 & 0.329\end{array}$

\section{Discussion}

Based on the results of hypothesis testing that has been described, the study habits and peer social support and contribute to the learning outcomes $32.9 \%$. In the following section, the discussion will be described for the variables examined in the study, including the following:

1. Overview of High School Students Study Habits

Results of data analysis showed that the overall average students' learning habits are in a higher category. This means learning habits of students to the learning outcomes have been good. Based on the achievement of each indicator is known that the ten indicators included in the high category are described as follows: master the material, understand the lessons take place, set the timetable is, learning at home, study together with friends, exchanging minds with friend, habit of reading books, the habit of memorizing textbooks, feeling before the exam, and prep yourself before the exam. Conditions of high student study habits need to be maintained, developed and improved. Habit learning is a form of behavior patterns are performed continuously so that a pattern of behavior habit is maintained so as to contribute to the learning outcomes. This is similar to the one delivered by Gie (1995) who argued learning habits are all the behavior exhibited monotonically from time to time in the framework of the implementation of the study. Habit learning is not a natural talent or innate, but learned behavior intentionally or the unconscious from time to time over and over again. Nasution (1992) also adds the higher old children become more responsible for the learning process because of the habit of including in it so the discipline of learning is becoming increasing important.

Based on data from this study, counselor school plays an important role to develop the study habits of high potential that has been owned by the students, and to improve the indicators of study habits is still in the moderate achievements to be high and very high. Counselor school need to continue to train and develop students' learning habits in order not to decrease, if the study habits has decreased then it will require a long process to improve it. Therefore, counselor school can provide multiple services to students such as mastery of information services and content services. Although it must be supported by other services in accordance with the aim to improve students' study habits.

2. Contributions to the Study Habits Study Results

The results showed that the study habits are contributing significantly to the learning outcomes. This statement is obtained based on a series of data analysis showed that the contribution of the habit of learning outcomes toward $32.9 \%$. That is, the study habits is one of the factors that contribute to the learning outcomes. This is in accordance with the opinion of Ozsoy (Rosyida 2009) that students who have good study habits tend to live with discipline and be responsible for every act of learning to achieve higher learning outcomes.

Based on the above, it is understood that the importance of study habits on learning outcomes. One of which must be improved and developed in every individual is habit learning. In this research study habits already at the high category. Therefore, school counselor and subject teachers need to improve study habits, then the learning outcomes students will increase. One of 
the services that could be implemented to improve the learning outcomes of study habits is the mastery of information services and content services.

\section{Conclusion}

Based on the findings and discussion of the research results, it can be stated conclusions, as follows:

1. Learning habits on average in Senior high school at the high category, this means good study habits have a role in student learning outcomes.

2. There is a significant contribution between habit learning on learning outcomes. Study habits contributed $32.9 \%$ to the learning outcomes. That is, the higher the students 'learning habits, the higher the students' learning outcomes. This means that students have good study habits to follow the lessons, independent study at home, study groups, study textbooks, exam.

\section{References}

Alizamar. (2016). Teori Belajar \& Pembelajaran. Yogyakarta: Media Akademi.

Medistiara, Y. (2016). Nilai Rata-rata UN SMA 2016 Turun 6 Poindari Tahun 2015.

(https://news.detik.com/berita/3206228/nilai-rata-rata-un-sma-2016-turun-6-poin-dari-tahun-

2015). In accesed, Monday 09 May 2016, 17:35 p.m.

Djaali. (2014). Education Psychology. Jakarta: Bumi Aksara.

Gie, T., L. (1995). The effective study step. Yogyakarta: Universitas Gajah Mada Press

Nasution, N. (1992). Education Psychology Jakarta. Dikti Depdikbud.

Rosyida, F. (2016). Pengaruh Kebiasaan Belajar dan Self-Efficacy terhadap Hasil Belajar Geografi di SMA. Jurnal Pendidikan Geografi. 2(2), 17-28.

Slameto. (2010.) Belajar dan Faktor-Faktor yang mempengaruhinya. Jakarta: Rineka Cipta.

Syah, M. (2011). Education Psycholog.y Bandung: Remaja Rosdakarya. 